Historic, Archive Document

Do not assume content reflects current scientific knowledge, policies, or practices. 
62.97

1932

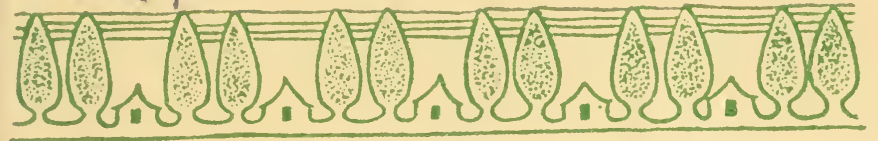

IVERTEREN

NURIEIR COMIDANY

Evergreen/peciadists

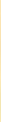

sositivitus
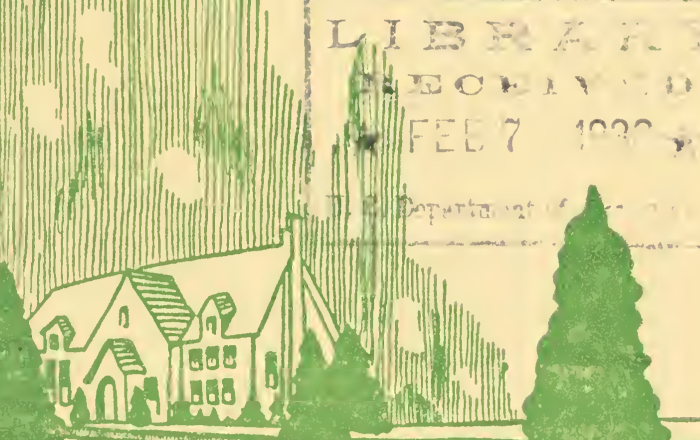

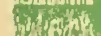

Thy

now

Nom

wo nom

1.

min

(4)

(n)

(1)

산

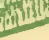

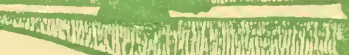

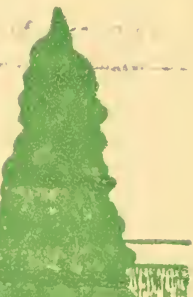

-
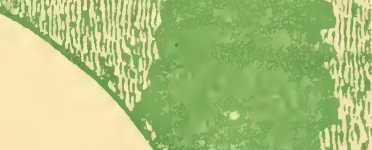

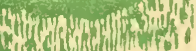

(i) $\int P^{2}$ sis

Wii

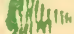

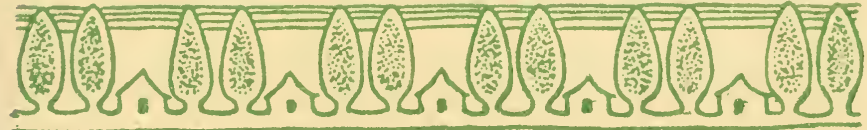




\section{THE OPPORTUNITY OF A}

\section{Lifetime!}

1932 marks the 200th anniversary of the birthday of the Father of Our Country, GEORGE WASHINGTON

One of the outstanding slogans of the George Washington Bi-Centennial is-

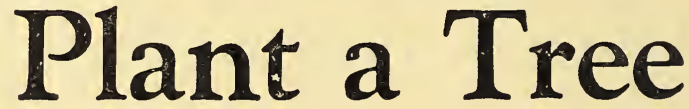

to commemorate this two hundredth anniversary, which will come only once in our lives. Nothing that you can ever do will have a more everlasting effect upon everyone concerned, and society as a whole. It would be a living monument to this great period.

Here are a few varieties of shade trees and evergreens that we feel are especially suited for this purpose. Beauty, hardiness, and longevity are characteristics of all those listed.

Each

White Spruce, specimen tree, 2-3 feet ..\$2.50

White Spruce, specimen tree, 3-4 feet .. 3.95

Colo. Blue Spruce, specimen tree, $2-21 / 2$ feet 6.95

Colo. Blue Spruce, specimen tree, $2 \frac{1}{2}-3$ feet 8.25

Colo. Green Spruce, specimen tree, $2-2 \frac{1}{2}$ feet

American Elm, 6-8 feet 2.50

American Elm, 8-10 feet 1.40

American Elm, 10-12 feet

Hard Sugar Maple, 6-8 feet

Evergreens shipped with ball of earth.

Very special prices on quantity lots.

Prices on request. 


\section{SPRING 1932}

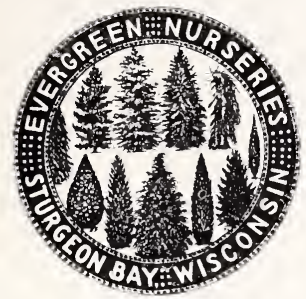

For sixty-eight years the emblem of

Quality, Satisfaction and honest dealing

\section{GOOD TREES}

\section{GROWN RIGHT...DUG RIGHT PACKED RIGHT}

$\mathrm{T}$

IIAT'S what we aim at and we want to prove it to you. In this, our latest catalog, which we take pleasure in presenting to you, we have listed the many varieties of trees that we grow. Just make out your order, following the directions given under Terms and Conditions, mail it to us and we are sure you will find that your confidence has not been misplaced. We will give your order our very best attention and do all in our power to make you a satisfied customer; for we know that a satisfied customer is by far the best advertisement any business can have.

\section{Important Information READ IT}

Since the day this nursery was established in 1864, it has been operated without a break by the same family. This means that we attained stability, as well as an enviable reputation among the nurserymen of the country. Our business in the past has been about 95 percent wholesale, but we have decided to enter the retail field and offer our customers a grade of stock that is hard to get from dealers and at a price that is very reasonable.

Rather than offer a large descriptive catalog, the cost of which would make it necessary for us to make a greater margin of profit, we are offering this simple catalog. This means that we can sell cheaper. Look this through carefully as there may be some item in which you are interested hidden down in some corner, and if you cannot find what you want, write us, for we may have it.

The practical experience gained from more than sixty years of growing evergreens and ornamental trees is at your service. It is yours for the asking. If you wish specific planting instructions, are in doubt as to the best varieties to plant or are confronted with any other problem, write us and we will gladly help you solve it, if we can.

TERMS and CONDITIONS on inside of back cover 


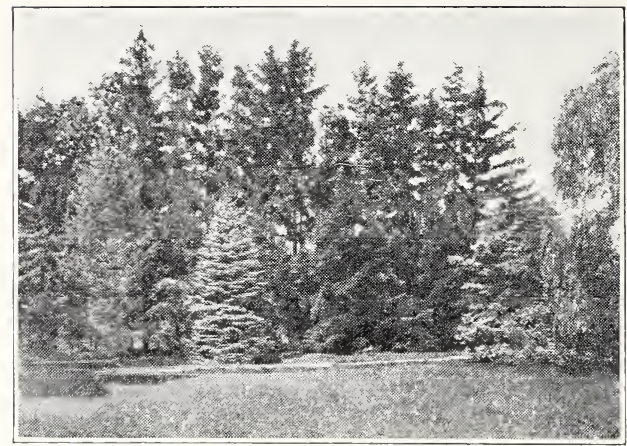

Nothing surpasses the evergreen for ornamental or windbreak purposes

\section{EVERGREENS}

\section{PRICES AND SIZES TO SUIT EVERY NEED} AND PURSE

Many retail catalogs list only the larger more expensive evergreens, and do not list any seedlings, once or twice transplanted evergreens. Of course, for immediate effects, the larger evergreen, which is usually handled with a ball of earth is a splendid article, and well worth the money. But for folks who are willing to wait and watch their trees grow, small evergreens in once or twice transplanted grades can be purchased for only a fraction of the cost of the larger trees. Then again, when one wants thousands of trees for reforestation, or extensive plantings, small two and three year seedlings' can be purchased at a surprisingly low cost. Thus you can buy evergreens from us to suit your every purpose and purse.

\section{SEEDLING EVERGREENS}

Seedlings are trees which have been grown from seed, but have never been removed from the original seed bed, that is, they have never been transplanted. They are at least two years old before we offer them for sale. If you are in need of a large number of evergreens, or if you do not care to spend much for your stock, and are willing to wait for them to grow, seedling evergreens will certainly solve your problems. Specific planting instructions with every order tells you just how to care for them.

\section{ONCE TRANSPLANTED EVERGREENS}

If you are in the market for quite a number of evergreens ready to go into the field, our small once transplanted stock would fill your needs. Once transplanted means trees that have been taken from the seed beds and planted in rows under shades and overhead irrigation. Here they are allowed to remain two years. This produces a tree that will stand transplanting well, and can be either planted in their permanent place or placed in the field and grown on into specimen stock. This stock does not need shade as in the case of seedlings. Once transplanted trees are indicated in this catalog by symbol $\mathrm{X}$.

\section{TWICE TRANSPLANTED EVERGREENS}

Twice transplants, are trees that have been taken from the once transplanted bed and planted in wide rows directly in the field. Twice transplanted trees are the next best grade to specimen trees. The more times a tree is transplanted, the better the tree. Twice transplanted trees are indicated in this catalog by the symbol XX. 


\section{SPECIMEN EVERGREENS \\ Balled and Burlapped}

Balling and burlapping an evergreen is the best known method of handling the larger and more expensive evergreens. It consists of digging the tree with the ball of earth which is wrapped with burlap. This permits the least possible disturbance of the tree in transplanting. Remember these trees are all perfect shaped specimens.

Our B. \& B. evergreens are all specimen trees, three or more times transplanted, and just the thing for an immediate showing on your lawn. When trees are balled and burlapped it is indicated by B. \& B.

\section{«《 $\ll ~ 》 ~ 》$}

Norway Spruce (Picea Excelsa) This is the most popular tree in the Spruce family. It is one of fastest growers, is very hardy, and one of the most universally planted evergreens. Especially suited for windbreaks, Christmas trees, and reforestation purposes, besides being very valuable as a fast growing ornamental evergreen. Pyramidal is shape with dark green needles.

Once transplanted trees are indicated by $X$

Twice transplanted trees are indicated by $\mathrm{XX}$

3- 5 in. Seedlings

$5-10$ in. Seedlings

$4-6$ in. $\mathrm{X}$

$6-8$ in. $\mathrm{X}$

$8-12$ in. $X$

$1-1 \frac{1}{2}$ ft. XX

$11 / 2-2$ ft. XXX $B \& B$ specimen $\$ 1.40$ each $\$ 12.00$ per 10

2 - 3 ft. XXXX B\&B specimen $\$ 1.95$ each $\$ 17.00$ per 10

3 - $4 \mathrm{ft}$. XXXX B\&B specimen $\$ 2.90$ each $\$ 24.00$ per 10

White Spruce (Picea Alba) A native tree of the Great Lakes section. Grows more compact than does the Norway Spruce, but rot as rapidly. Many trees have a bluish-white tinge to them. Grows to a height of 25 feet, and is very hardy. Excellent for windbreak, specimen or background planting.

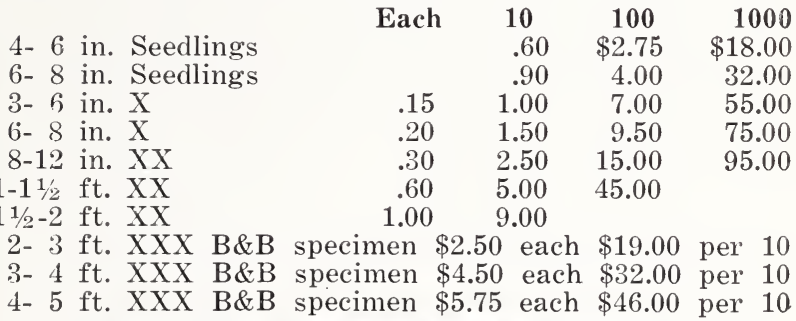

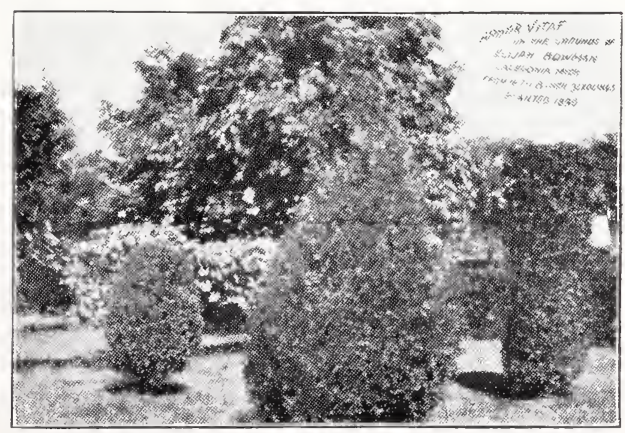


Black Hills Spruce (Picea Canadensis Albertiana) A native of the Black Hills. It is quite similar to the White Spruce, but more compact and slower growing. The new growth in the spring has somewhat the bluish color of a Colorado Blue Spruce. Will grow to a maximum height of from 25-35 feet, but because of its slow growth, it can be used where space is limited.

$3-6$ in. Seedlings
$6-8$ in. $X$

$\begin{array}{lll}\text { Each } & 10 & 100\end{array}$

$8-10$ in. XX
$1-1 \frac{1}{2}$ ft. XX

$.75 \$ 5.00$

1000

$\begin{array}{rrr}.20 & 1.20 & 9.50 \\ .25 & 2.00 & 16.00\end{array}$

$\begin{array}{lll}.85 & 7.75 & 68.00\end{array}$

$1 \frac{1}{2}-2$ ft. XXX B\&B specimen $\$ 2.25$ each $\$ 18.00$ per 10 2 - 3 ft. XXX B\&B specimen $\$ 3.50$ each $\$ 32.00$ per 10 3- 4 ft. XXX B\&B specimen $\$ 5.50$ each $\$ 50.00$ per 10

Colorado Blue Spruce (Picea Pungens Glauca) Everyone knows and wants the Colorado Blue Spruce. It has long: held its place as the Aristocrat of Evergreens. When you get Colorado Blue Spruce from us you get REAL BLUE TREES. We guarantee them to be of good color. If you can't afford the larger trees here is an opportunity to get 50 trees in the smaller sizes for the price you usually pay for one tree.

$\begin{array}{rrrrr}2-4 \text { in. Seedlings } & \text { Each } & \mathbf{1 0} & \mathbf{1 0 0} & \mathbf{1 0 0 0} \\ 3-6 \text { in. Seedlings } & & & \$ 3.95 & \$ 24.00 \\ 2-4 \text { in. X } & .15 & .80 & 5.95 & 42.00 \\ 4-6 \text { in. X } & .20 & 1.50 & 10.75 & 45.00 \\ 6-8 \text { in. XX } & .45 & 3.50 & 25.00 & \\ 8-12 \text { in. XX } & .90 & 5.50 & 38.00 & \\ 12-18 \text { in. XX } & 1.50 & 10.00 & 85.00 & \end{array}$

$11 / 2-2$ ft. XXX B\&B specimen $\$ 4.90$ each $\$ 45.00$ per 10 $2-2 \frac{1}{2}$ ft. XXX B\&B specimen $\$ 6.95$ each $\$ 59.00$ per 10 $21 / 2-3$ ft. XXX B\&B specimen $\$ 9.00$ each $\$ 85.00$ per 10

Colorado Green Spruce (Picea Pungens) Same as Colorado Blue Spruce except that instead of being blue in color they are green.

$11 / 2-2$ ft. B\&B specimen $\$ 1.95$ each $\$ 17.00$ per 10

2 - 3 ft. B\&B specimen $\$ 2.95$ each $\$ 25.00$ per 10

3- $4 \mathrm{ft}$. B\&B specimen $\$ 5.00$ each $\$ 45.00$ per 10

Engelman Spruce (Picea Engelmanni) A native of the Rocky Mountains. Grows taller and more pryamidal than other spruce. Needles have a steel blue color and a distinct tendency to curve. An ornamental that deserves more attention than it receives.

$\begin{array}{lrrr} & 10 & 100 & 1000 \\ 3-6 \text { in. Seedlings } & & \$ 5.50 & \$ 38.00 \\ 3-5 \text { in. X } & \$ 1.10 & 8.95 & 60.00\end{array}$

Dwarf Mugho Pine (Pinus Mughus) One of the best and most popular dwarf ornamental evergreens. Unexcelled for foundation and rock garden planting. It seldom gets over 4 feet high, and may be kept to any desired height by shearing. Can be sheared to almost any shape, but its natural tendency is to grow spherical. A very hardy tree withstanding adverse conditions other trees will not tolerate. We import our own seed from Europe, and offer nothing but the very best strain.

$3-5$ in. Seedling's

Each $10 \quad 100 \quad 1000$

$4-6$ in. $X$

6- 8 in. $\mathrm{XX}$

$8-12$ in. $X X$

$\begin{array}{rrrr}.20 & 1.75 & \$ 4.95 & \$ 38.00 \\ .35 & 3.00 & 75.00\end{array}$

$\begin{array}{lll}.35 & 3.00 & 26.00\end{array}$

$\begin{array}{lll}.75 & 6.00 \quad 55.00\end{array}$

$12-15$ in. XXX B\&B specimen $\$ 2.00$ each $\$ 18.00$ per 10

$15-20$ in. XXX B\&B specimen $\$ 2.95$ each $\$ 25.00$ per 10

25 trees at 100 rates

250 trees at 1000 rates 
Scotch Pine (Pinus Sylvestris) A native of Europe where it has always been a very valuable timber and ornamental tree. It is very hardy, a rapid grower, and will do well on almost any kind of soil. It will grow where other evergreens will not. The needles are light green, very fragrant, and from 2 to 3 inches long.

3- 5 in. Seedlings

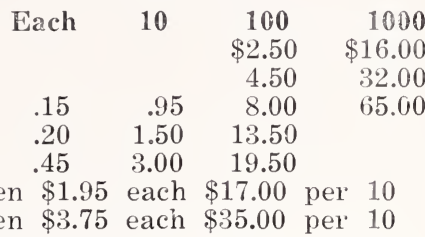

Austrian Pine (Pinus Nigra) Here is a tree that fills the need of the home owner in a large smoky city. Probably no other tree will withstand smoke and gas as will the Austrian Pine. It seems to have no effect upon its growth. Its growth is more compact than most of the tall growing Pines, and thereby makes an excellent tree for specimen lawn planting. It has slender straight needles from four to six inches long, and of a deep green color.

$3-5$ in. Seedlings

$\begin{array}{lrrrr} & \text { Each } & 10 & 100 & 1000 \\ 3-5 \text { in. Seedlings } & & & \$ 2.50 & \$ 16.00 \\ 5-8 \text { in. Seedlings } & & & 5.50 & 32.00 \\ 4-6 \text { in. X } & .12 & .90 & 8.00 & 68.00 \\ 6-8 \text { in. X } & .18 & 1.50 & 12.00 & 95.00 \\ 10-12 \text { in. XX } & .50 & 3.50 & 28.00 & \\ 1-1 / 2 \text { ft. XX } & .75 & 5.00 & 40.00 & \end{array}$

$11 \frac{1}{2}-2$ ft. XXX B\&B specimen $\$ 2.00$ each $\$ 18.00$ per 10

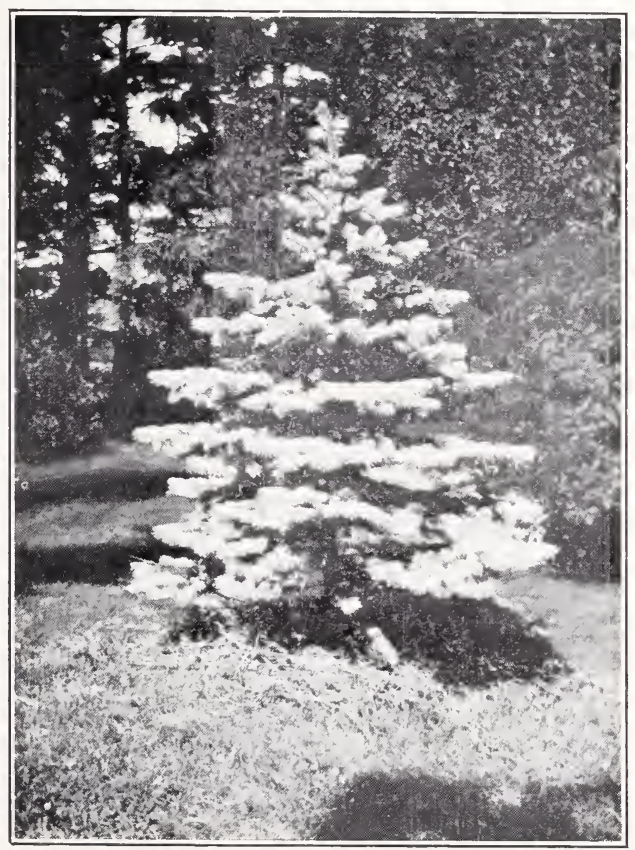

Colorado Blue Spruce 
Ponderosa Pine (Pinus Ponderosa) Sometimes called Western or Bull Pine. It is a native of our western states. The needles are of a light green and even longer than those of the Austrian Pine. The needles are also very soft in texture, and have three in a sheath.

3-5 in. Seedlings

$\begin{array}{ccrr}\text { Each } & 10 & 100 & 1000 \\ & & \$ 2.50 & \$ 19.00 \\ .10 & .80 & 4.00 & 26.00 \\ & & 7.00 & 60.00\end{array}$

5-7 in. Seedlings

$4-6$ in. $\mathrm{X}$

Norway Pine (Pinus Resinosa) A native of the north
central states, and a very hardy tree. The needles are slender, very flexible, dark green and lustrous.

$\begin{array}{lrrrr} & \text { Each } & \mathbf{1 0} & \mathbf{1 0 0} & \mathbf{1 0 0 0} \\ 3-6 \text { in. Seedlings } & & & \$ 3.00 & \$ 21.00 \\ 6-8 \text { in. X } & .12 & .90 & 8.00 & 70.00 \\ 8-12 \text { in. XX } & .25 & 2.00 & 16.00 & \end{array}$

Am. Arbor Vitae (Thuya Occidentalis) Sometimes called White Cedar. A very valuable and widely planted tree. Used for reforestation, ornamental and hedge purposes. It responds very well to shearing, and can be sheared into hedges or perfect individual specimens.

\begin{tabular}{rrrrr} 
& Each & $\mathbf{1 0}$ & \multicolumn{1}{c}{$\mathbf{1 0 0}$} & $\mathbf{1 0 0 0}$ \\
$3-6$ in. Seedlings & & & $\$ 2.00$ & $\$ 15.00$ \\
$6-8$ in. Seedlings & & & 3.00 & 26.00 \\
$6-10$ in. X & .10 & .80 & 7.00 & 60.00 \\
$10-12$ in. X & .15 & 1.00 & 9.00 & 80.00 \\
$12-15$ in. XX & .20 & 1.75 & 15.00 & \\
$15-20$ in. XX & .25 & 2.25 & 20.00 & \\
$20-24$ in. XX & .35 & 3.00 & 27.00 &
\end{tabular}

$2-3$ ft. XXX B\&B specimen $\$ 2.25$ each $\$ 20.00$ per 10

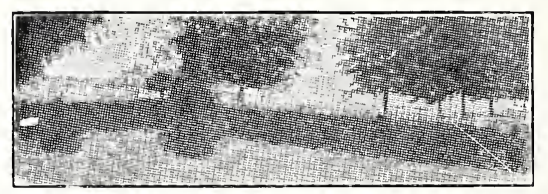

Arbor Vitae Hedge and Sheared Specimens

Globe Arbor Vitae (Thuya Occidentalis Globosa) We grow nothing but the Woodwards Globe Arbor Vitae. This is a far superior strain to the common Globe Arbor Vitae in that it is far more dense and compact growing. Woodwards Globe Arbor Vitae is a dwarf ornamental tree, growing absolutely round or globular. Just the tree for foundation plantings, or in any formal planting. These trees are not grown from seed but from cuttings.

6- 8 in. $\mathrm{XX}$

$8-10$ in. $X X$

10-12 in. XXX B\&B specimen

12-15 in. XXX B\&B specimen
Each $\quad 10 \quad 100$

$.40 \$ 3.50 \quad \$ 25.00$

$\begin{array}{lll}.60 & 5.00 & 40.00\end{array}$

$\$ 1.50$ each $\$ 14.00$ per 10 $\$ 2.50$ each $\$ 20.00$ per 10

\section{SPECIAL NOTICE}

Sometimes our customers have need for a number of large trees for a mass planting, a windbreak, or a screen, and it is not necessary that the trees be specimen stock. If you are in need of such material, write us at once, for we can quote you some very special low prices on just what you want. 
Pyramidal Arbor Vitae (Thuya O. Pyramidalis) Another excellent Arbor Vitae. Grows strictly pyramidal in shape, and plays an important part in all landscape work. Excellent for entrance way plantings, one on each side, as it lends formality and height.

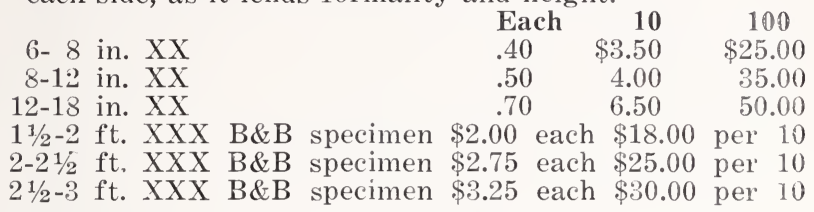

Siberian Arbor Vitae (Thuya 0 . Wareana) A semi-dwarf never growing larger than seven or eight feet. Is very hardy, as the name implies, and excellent for either specimen or hedge planting. Grows conical in form, but more broad than other Arbor Vitae. Foliage of a very dark green.

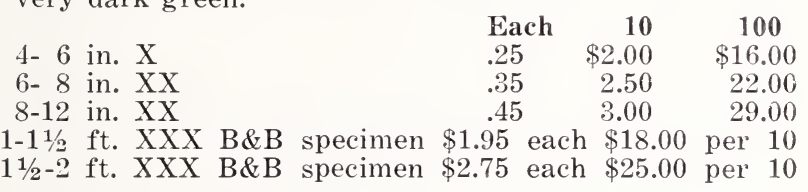

The Juniper Family

The Juniper family contains many varieties especially suited for foundation and rock garden planting. With the exception of Red Cedar, Prostrate Juniper, Chinese Juniper, and Colorado Juniper, practically all other Junipers are grown from either cuttings or they are grafted on the roots of either Red Cedar or Chinese Juniper. We are listing only the best and hardiest of the Junipers.

Pfitzers Juniper (Juniperus Pfitzeriana) One of the verv best of the low growing Junipers. Does equally as well in Canada as in Texas. Can be made to grow upright by staking the leader, or allowed to grow in prostrate form. Irregular in growth, forming an excellent contrast to more formal evergreens. By far one of the most popular of the Junipers.

$6-8$ in. $\mathrm{XX}$

8-10 in. XX

$11 / 2-2$ ft. XXX B\&B

$2-2^{1 / 2}$ ft. XXX B\&B

$\begin{array}{lrr}\text { Each } & 10 & 100 \\ .35 & \$ 3.00 & \$ 28.00 \\ .55 & 4.75 & 45.00 \\ 2.50 & 22.00 & \\ 3.95 & 35.00 & \end{array}$

Silver Red Cedar (Juniperus Virg. Glauca) A grafted tree of unusual beauty. Grows to a broad compact pyramid with a distinct silver color, more pronounced when the new growth comes out in the spring.

$8-12$ in. $\mathrm{XX}$

$12-18$ in. XX

11/2-2 ft. XXX B\&B specimen

$2-21 / 2 \mathrm{ft}$. XXX B\&B specimen

21/2-3 ft. XXX B\&B specimen

3- $1 \mathrm{ft}$. XXX B\&B specimen
Each

$.95 \$ 9.00$

1.25

2.95

3.50

4.75

7.50
10

12.00

27.00

32.00

45.00

70.00

\section{SATISFIED CUSTOMERS} bill.

"Enclosed find P. O. Money Order, as per your"

"I must say that I am very weil pleased with the trees. They were in fine condition and well packed."

HENRY WISTRICH, Elkader, Iowa. 


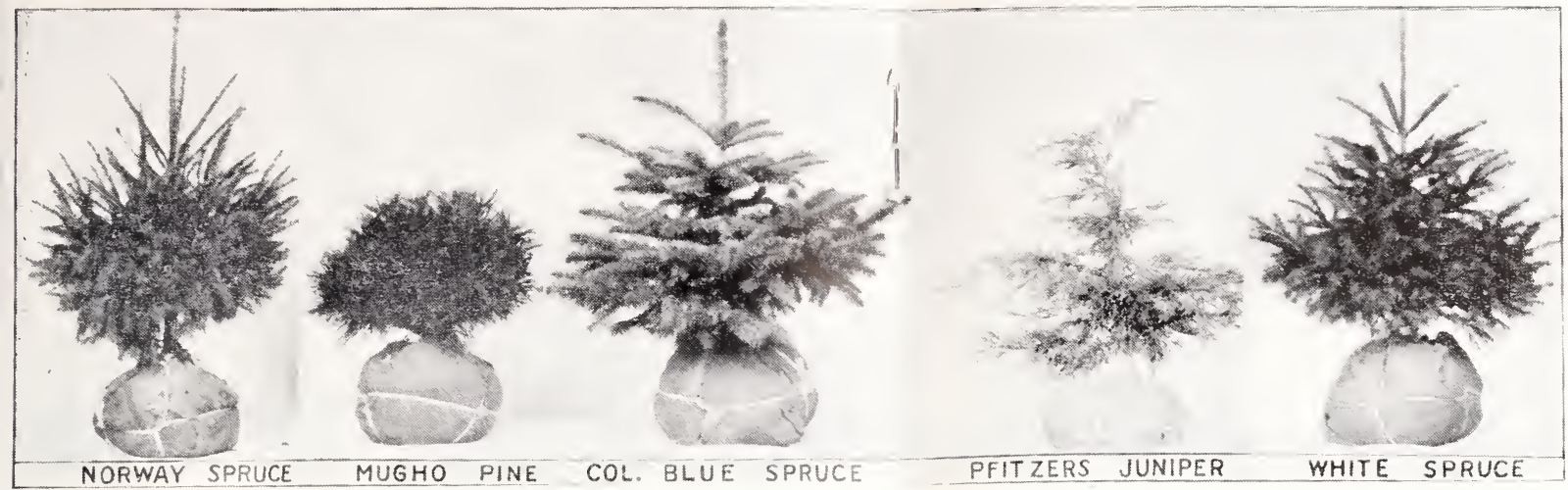

A Few of Our Specimen Balled a nd Burlapped trees

Cannart Juniper (Juniperus Virg. Cannarti) Similar in type and growth to Silver Red Cedar except that it is green instead of b!ue. Also a grafted tree.

\begin{tabular}{|c|c|}
\hline $8-12$ in. $\mathrm{XX}$ & $\begin{array}{c}\text { Each } \\
.80\end{array}$ \\
\hline $2-18$ in. XX & 1.20 \\
\hline $1 / 2-2$ ft. XXX B\&B specimen & 2.50 \\
\hline$-21 / 2 \mathrm{ft}$. XXY B\&B specimen & 3.25 \\
\hline $1 / 2-3 \mathrm{ft} . \mathrm{XXX}$ B\&B specimen & 4.25 \\
\hline 3- $4 \mathrm{ft}$ XXX B\&B specimen & 6.00 \\
\hline
\end{tabular}

Red Cedar (Juniperus Virginiana) A tall, conical growing Juniper, with dense foliage. Foliage of a dark green in summer turning copper bronze in fall and winter. An excellent tree to lend additional color to a group of evergreens. Responds readily to shearing.

$3-6$ in. Seedlings

6- 8 in. $\mathrm{X}$

$8-12$ in. $\mathrm{XX}$

$12-18$ in. XX

$11 / 2-2$ ft. $X X$

$\begin{array}{lccr}\text { Each } & 10 & 100 & 1000 \\ & & \$ 5.00 & \$ 40.00 \\ .15 & 1.25 & 10.00 & 90.00 \\ .25 & 2.00 & 18.00 & \\ .35 & 3.00 & 28.00 & \\ .65 & 6.00 & 55.00 & \end{array}$

Prostrate Juniper (Junipers Communis Depressa) A very interesting evergreen, growing low with a distinct spreading habit, seldom reaching over 2 feet in height. The underside of the needles always have a silvery color, and in the fall and winter the tree takes on a characteristic rich copper bronze shade.

\begin{tabular}{|c|c|c|}
\hline & Each & 10 \\
\hline $4-6$ in. $\mathrm{X}$ & .20 & $\$ 1.50$ \\
\hline $6-8$ in. $\mathrm{XX}$ & .40 & 3.50 \\
\hline $1-1 \frac{1 / 2}{\mathrm{ft}}$. XXX B\&B & 2.00 & 18.00 \\
\hline $11 / 2-2$ ft. XXX B\&B & 2.75 & 25.00 \\
\hline $2-3 \mathrm{ft} . \mathrm{XXX} \mathrm{B} \& \mathrm{~B}$ & 3.75 & 35.00 \\
\hline
\end{tabular}

Goldtip Juniper (Juniperus Virg. Elegantissima) This tree never fails to attract attention due to the fact that the tips come out in the spring a rich yellow, gradually fading into an old gold toward fall. A semi dwarf, conical in shape, reaching a maximum of 10 to 12 feet.

8-12 in. $\mathrm{XX}$

$1-1 \frac{1}{2}$ ft. $X X X \quad B \& B$

$11 / 2-2$ ft. XXX B\&B

\begin{tabular}{|c|c|}
\hline Each & 10 \\
\hline .90 & $\$ 8.00$ \\
\hline $\begin{array}{l}3.50 \\
4.75\end{array}$ & $\begin{array}{r}32.00 \\
45.00\end{array}$ \\
\hline
\end{tabular}

100

\section{Norway Spruce}

and

\section{Scotch Pine}

Windbreak

on our

Grounds

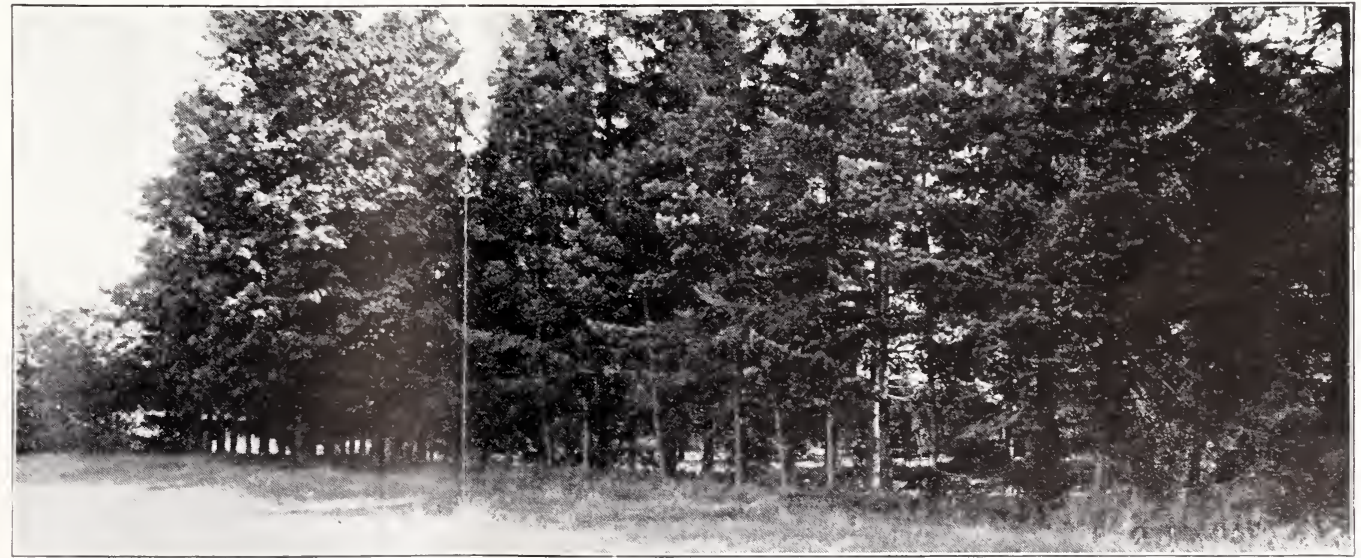

\section{See Our Windbreak Offer Page 12}

Five of the same variety and size at the 10 rate. Each $\mathrm{X}$ indicates one transplanting, $\mathrm{B} \& \mathrm{~B}$ signifies balled and burlapped. 
Hill Dundee Juniper (Juniperus Virg. Pyramidaformia) A conical, very dense growing Juniper. Its outstanding features are its compactness of growth and the deep copper bronze color that it takes on in the fall.

6- 8 in. $\mathrm{XX}$

$11 / 2-2$ ft. XXX $B \& B$

2- $3 \mathrm{ft}, \mathrm{XXX} B \& B$

$\begin{array}{ccc}\text { Each } & \mathbf{1 0} & \mathbf{1 0 0} \\ .90 & \$ 8.50 & \$ 75.00 \\ 3.50 & 32.00 & \\ 6.00 & 55.00 & \end{array}$

Creeping Juniper ( $J$ uniperus Horizontalis) Excellent for rock gardens, for as its name implies, it creeps along the ground and over rocks, forming a complete ground cover. A delicate green in summer, turning bronze in fall.

4- 6 in. $\mathrm{X}$

$1-1 \frac{1}{2}$ ft. XXX B\&B

$\begin{array}{ccc}\text { Each } & 10 & 100 \\ .35 & \$ 3.00 & \$ 25.00 \\ 3.00 & 25.00 & \end{array}$

Andorra Juniper (Juniperus C. D. Plumosa) A low growing spreading Juniper, but does not cling to the ground as does the creeping Juniper. Grows a little higher than the strict creeping forms, offering an excellent contrast. As soon as the first sharp frosts come this Juniper turns a rich silvery purple.

\begin{tabular}{|c|c|}
\hline $6-10$ in $\mathrm{XX}$ & $\begin{array}{c}\text { Each } \\
.35\end{array}$ \\
\hline
\end{tabular}

Savin Juniper (Juniperus Sabina) A many branched dwarf, seldom growing over three feet high, but spreading in nature. Dark green the entire year, and forms an excellent planting in front of larger evergreens or as a specimen.

6- 8 in. $\mathrm{XX}$

Each $\quad 10 \quad 100$

$8-10$ in. $\mathrm{XX}$

$1-1 \frac{1}{2}$ ft. XXX $B \& B$

$\begin{array}{lll}.35 & \$ 3.00 & \$ 28.00\end{array}$

$\begin{array}{lll}.55 & 4.75 & 45.00\end{array}$

Balsam Fir (Abies Balsamae) A native of the north central states, and known for its fragrant "balsam odor". Also the most desirable Christmas tree, due to both its fragrance, and the fact that it will retain its needles longer under artificial heat than any other evergreen. A very adaptable tree to varied soil conditions, doing equally as well on low as on high land, on poor as well as fertile soils.

3- 6 in. Seedlings

$\begin{array}{rrrr}\text { Each } & \mathbf{1 0} & \mathbf{1 0 0} & \mathbf{1 0 0 0} \\ & & \$ 2.75 & \$ 18.00 \\ & & 3.50 & 25.00 \\ .15 & 1.00 & 9.00 & 75.00 \\ .20 & 1.50 & 12.00 & 95.00 \\ .30 & 2.50 & 19.00 & \\ .45 & 3.50 & 29.00 & \end{array}$

$6-10$ in. Seedlings

4- 6 in. $\mathrm{X}$

6- 8 in. $X$

$8-12$ in. $\mathrm{XX}$

$12-18$ in. $\mathrm{XX}$

$\begin{array}{lll}.45 & 3.50 & 29.00\end{array}$

$1 \frac{1}{2}-2$ ft. XXX B\&B specimen $\$ 1.95$ each $\$ 17.00$ per 10

$2-3 \mathrm{ft}$. XXX B\&B specimen $\$ 2.75$ each $\$ 25.00$ per 10

3- 4 ft. XXX B\&B specimen $\$ 3.95$ each $\$ 35.00$ per 10

4- $5 \mathrm{ft}$. XXX B\&B specimen $\$ 4.95$ each $\$ 45.00$ per 10

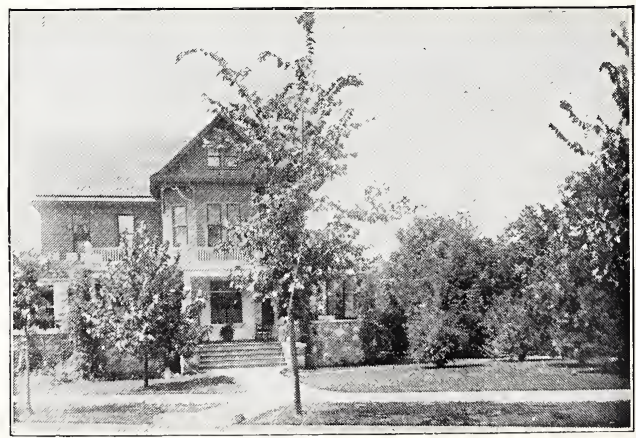


Concolor Fir (Abies Concolor) Also known as White, Western or Silver Fir. A native of the Rocky Mountains this beautiful tree always receives a prominent place in all landscape plantings. Very symetrical, with long soft needles that vary in color from light green to deep blue. Very hardy, and resistant to all disease.

$\begin{array}{lrrrr} & \text { Each } & 10 & 100 & 1000 \\ 4-6 \text { in. Seedlings } & & & \$ 7.00 & \$ 58.00 \\ 6-8 \text { in. Seedlings } & & & 9.95 & 85.00 \\ 4-6 \text { in. X } & .15 & 1.30 & 11.00 & \\ 8-12 \text { in. XX } & .30 & 2.50 & 21.00 & \\ 1-1 / 2 \text { ft. XX } & .75 & 6.50 & & \end{array}$

Douglas Fir (Pseudosuga Douglassi) Another excellent fir native of the Rocky Mountains. It is a hardy grower, with long graceful branches. Our Douglas Fir seed comes from Colorado where the best type of Douglas Fir grows. A majestic tree maintaining its beauty into old age.

$\begin{array}{rrrrr} & \text { Each } & 10 & 100 & 1000 \\ 3-6 \text { in. Seedlings } & & & \$ 3.95 & \$ 28.00 \\ 6-8 \text { in. Seedlings } & & & 5.50 & 36.00 \\ 8-10 \text { in. Seedlings } & & & 7.50 & 50.00 \\ 4-6 \text { in. X } & .10 & .70 & 6.00 & \\ 1-11 \% \text { ft. XX } & .30 & 2.50 & 21.00 & \end{array}$

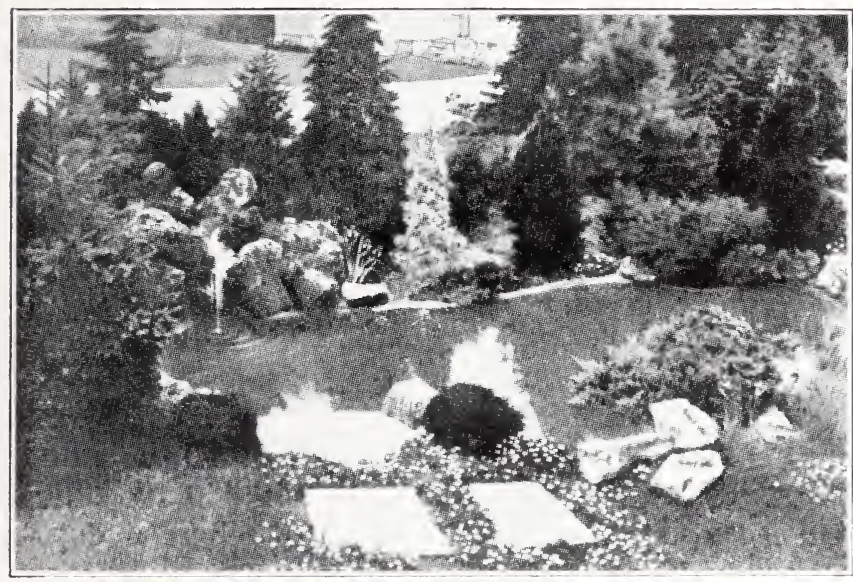

No rock garden is complete without Evergreens

\section{TREES}

I think that I shall never see a poem lovely as a tree.

A tree whose hungry mouth is prest against the earth's sweet flowing breast.

A tree that looks at God all day, and lifts her leafy arms to pray;

A tree that may in summer wear, a nest of robins in her hair;

Upon whose bosom snow has lain, who intimately lives with rain.

Poems are made by fools like me, but only God can make a tree. 


\section{Our Big Windbreak Offer}

In this day when all our forests are being cut down one feels the winter winds more than ever before, especially in the open country. A windbreak affords not only protection but adds materially to the beauty of the home as well as to its value.

Windbreaks are planted in rows, usually two, ten feet apart, and trees ten feet apart in the row.

\begin{tabular}{|c|c|c|}
\hline Scotch & Norway & White \\
\hline Pine & Spruce & Spruce \\
\hline $\mathrm{XXX}$ & $\mathrm{XXX}$ & XXX \\
\hline$\$ 7.00$ & $\$ 6.00$ & $\$ 9.00$ \\
\hline 11.00 & 9.00 & 16.00 \\
\hline 1. & 15.00 & 29 . \\
\hline
\end{tabular}

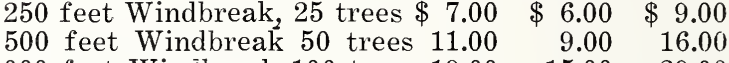

1000 feet Winäbreak 100 trees $19.00 \quad 15.00 \quad 29.00$

These trees are all three times transplanted and are 1-1/2 feet high. Can also supply trees $1 \frac{1 / 2-2}{\text { feet, }}$ 2-3 feet, 3-4 feet at very low prices. Write for special quotations. Any of these trees will make you an effective windbreak for very little money. These three varieties are, without question the very best for windbreak purposes. Every windbreak is accompanied with complete instructions and guaranteed to be satisfactory in every respect.

\section{Christmas Tree Plantations A Real Money Maker}

You undoubtedly realize how scarce good Christmas trees are becoming, over five million used in United States every year. Christmas tree plantations are the only solution, some already having been started. NORWAY SPRUCE is the ideal tree for this purpose as it grows very fast and is extremely hardy. If you are interested we will give you special prices on larger quantities as well as more information regarding these plantations. A small piece of waste land planted with our once transplanted NORWAY SPRUCE will soon grow into money. Norway Spruce is also used extensively for reforestation.

The growing of Christmas trees is a very fertile field, especially so for those who get into it early. Let us quote for planting this spring.

\section{ROSES}

\section{(Hybrid Perpetuals)}

Our roses are all No. 1 stock field grown. These roses have all actually bloomed in our nursery rows, so if you want large husky bushes,- -here they are.

PRICES : $75 \mathrm{c}$ each, $\$ 7.00$ per 10

Frau Karl Druschki. A snow waxy white. A marvel of beauty in both bud and bloom.

General Jacqueminot. A brilliant crimson.

Magna Charta, Pink and carmine. A very heavy bloomer.

Paul Neyron, large flower, deep rose color.

Ulrich Brunner, long stemmed, light red.

American Beauty, deep pink. 


\section{PERENNIALS}

No landscape picture is complete unless some bright color is introduced, which can be accomplished only by means of perennials. Evergreens are needed for backgroundsi and specimens, but the dash of color supplied by a perennial border will complete the picture. We grow all our own perennials, so you will find them of the same high quality as our evergreens.

All perennials are two year field grown, and are just the plants for quick results in your border.

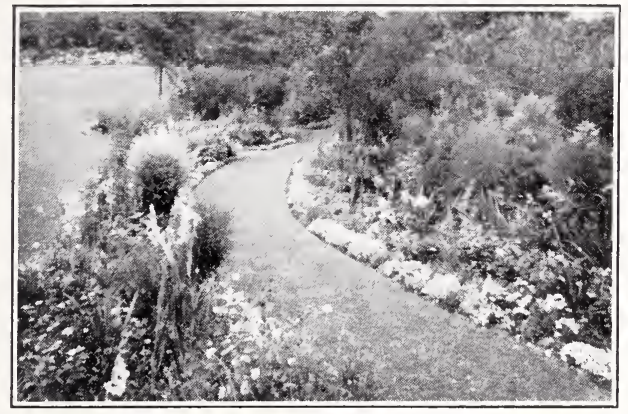

The varieties marked with an (*) are especially suited for rock garden planting.

Prices of perennials-20c each, 3 for $55 \mathrm{c}, 10$ for $\$ 1.75$.

*Alysum (Madwort)-Broad masses of bright yellow flowers early in spring. Excellent for rockery or borders. Foliage in heavy mats.

Achillea ('The Pearl)-Pure white, double flowers all summer. Excellent for cutting.

Anchusa (Dropmore)-Tall spikes of beautiful blue flowers, blooming all summer. 4-5 feet.

Anemone (Whirlwind)-Excellent double white flowers 2-3 feet.

*Aquilegia (Columbine) Single long spurred variety of colors, red blue, and white. May to June.

Aquilegia-(Mrs. Scott Elliotts long spurred hybrids) Beautiful flowers with very long spurred flowers. May to July. 2-3 feet.

*Babys Breath (Gypsophila)-Masses of small white flowers that lend a softness to every setting. Excellent for cut flowers. August and Sept. 2-3 feet.

*Bellis Perennis (Double Daisy)—An excellent rock garden plant never growing over 6 inches high. Shades of red, white, and pink.

Coreopsis ('Tickseed)-Masses of rich golden yellow flowers all summer. 3 feet.

Campanula Medium (Canterbury Bells)-Large flowers each resembling a cup and saucer. White and Blue. May and June. 2-3 feet.

*Carnations-Carnation-like flowers with a pronounced carnation odor. No garden is complete without them. In shades of red, white and pink. Blooms heavily.

"Daisy, Shasta Alaska-Most popular of the daisies. Handsome with large glistening white blossoms in June and July. 2 feet. 
Daisy, Hartje and Elder--Similar to the Shasta Daisy, but grows taller, and blooms very heavily. Also earlier than Shasta Daisy. 2-3 feet.

Delphinium Belladonna (Larkspur)-Large spikes of turquoise blue flowers. June until frost. $4 \mathrm{ft}$.

Delphinium Bellamosa-Large spikes of deep rich blue. 4-5 feet.

Delphinium, Wrexham strain of Hybrids-A very remarkable Delphinium. Very long spire-like spikes in large range of delicate shades. Blooms longer than other Delphinium. 5-6 feet.

*Dianthus Barbatus (Sweet William)-Deep masses of bloom in extremely rich and varied colors. An old fashioned flower that has always been very popular.

"Dianthus Deltoides (Maiden Pink)-A beautiful little prostrate plant with narrow leaves, with a profusion of small erimson flowers during July and August. Should be in every rock garden.

*Funkia (Day Lily)-Long narrow leaves, dull green produced in abundance. Lilac-like flowers. July and August.

Gaillardia (Blanket Flower) - Large brilliant flowers goldyellow with rich maroon-red center.

Hollyhocks-The best double hollyhocks in a choice of crimson, white, yellow and pink shades.

Lathyrus (Perennial Sweet Pea)--Clusters of large flowers on long stems produced in abundance. Will climb in same manner as will annual sweet pea.

*Lychnis (Maltese Cross)-Heads of vivid scarlet flowers. 3 feet. June to Sept.

*Mysctis (Forget-me-not)--A charming early blooming flower, usually in full bloom by Decoration Day. A profusion of delicate blue flowers. 1 foot.

Papaver, Oriental (Oriental Poppy)-Variety Princess Victoria Louise. A very large oriental poppy, sometimes with flower over 6 inches across. A beautiful perennial, giving plenty of color. May to June.

Physalis Francheti (Chinese Lantern)-Orange-red bladder like fruits in profusion during late summer and autumn.

*Platycoden (Chinese Bellflower)-Blue and white, beil shaped flowers all summer. Excellent in sunny border.

"Pyrethrum (Painted Daisy)-Very showy flowers in many shades growing on long stems throughout the sunımer, but more heavily during May and June. Very good for cut flowers.

\section{PHLOX}

PRICES-25c each, $\$ 2.25$ per 10

All Phlox offered are 2 year old plants and will bloom first year planted.

B. Compte-Very brilliant purple.

Bridesmaid-white with crimson eye.

Champ Elysee-Red.

Fernand Cortez-Crimson and bronze.

Miss Lingard-White, tall and very early.

Mrs. Chas. Dorr-Bright lavender.

Mrs. Jenkins-Pure white.

R. P. Struthers-Rosy carmine.

Rheinlander-Salmon pink.

Sunset-Deep rose pink.

Rosenberg-Reddish violet, showy. 


\section{ORNAMENTAL SHRUBS}

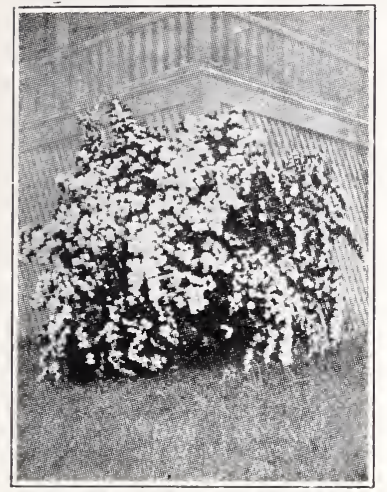

Spirea Van Houttei

Rather than offer a long assorted list of ornamental shrubs, many of which would not be best suited for your needs, we are listing only the generally accepted, most planted varieties. However, if you want some particular variety not listed, write us for we can furnish any variety of ornamental shrub that is hardy in Wisconsin.

All shrubs heavy and well branched. All varieties 2-3 feet or larger, except the smailer growing varieties.

PRICES-35c each $\$ 2.95$ per 10

Spirea Van Houttei-Commonly but erroneously called Bridal Wreath. By far one of the most popular shrubs. Very showy in early spring with masses of white flowers.

Spirea Frobelli-One of the very best dwarf Spireas. Never grows over 3 feet high. Excellent for foundation planting. Crimson.

Japanese Barberry-Very hardy. Stands a lot of abuse. Beautiful red foliage and red berries in the fall.

Hydrangea (Hills of Snow)-Beautiful large balls of snow white flowers in mid-summer. Never grows very large.

Viburnum Dentatum (Arrowood)-Bright colored foliage in fall with clusters of black berries.

Weigela, Rosea-Abundance of pink flowers in June.

Snowberry, White-Small pink flowers, with showy clusters of large white berries in fall and winter.

Indian Currant (Coralberry)_Masses of small red berries in fall.

Morrows Honeysuckle-White flowers in June followed by red berries.

Mock Orange (Syringa)-Abundance of creamy white flowers in May and June.

Tatarian Honeysuckle, Red-One of the most attractive shrubs. Grows to large proportions. Masses of pink flowers in June.

Amur River Privet-Ideal hedge plant, figure one plant for each foot. Responds readily to shearing.

\section{PEONIES}

Festiva Maxima-Pure white with crimson markings. One of the very best. 35c each.

Felix Crousse-A rich, brilliant, ruby red. 55c each.

Karl Rosenfield-An early brilliant red with no equal. Extremely vigorous, and tall growing. $75 \mathrm{c}$ each.

Avalanche-A late variety cream white. $45 \mathrm{c}$ each.

Mary Brand-An expensive peony, but worth the money. A vivid crimson in midseason. $\$ 1.00$ each.

Saral Bernhardt.-Apple blossom pink, very large and fragrant. $\$ 1.25$ each. 


\section{CHERRY TREES}

We are located right in the heart of the largest cherry orchards in the world-the famous Sturgeon Bay and Door County Cherry orchards. Because of our strategic location in that respect, we have always sold cherry trees to the local orchardists, and annual plantings in this section running as high as 100,000 or more trees annually. The cherry trees we handle are all grown in the famous Kaw valley in Kansas, by one of the largest and best growers there. This section produces some of the best trees grown. All trees are strictly No. 1 stock.

$$
\begin{array}{cccc} 
& \text { Each } & 10 & 100 \\
4-5 \text { feet } & .55 & \$ 4.50 & \$ 38.00 \\
3-4 \text { feet } & .40 & 3.50 & 25.00
\end{array}
$$

VARIETIES-Montmorency or Early Richmond.

Write for prices in quantities over 100

We can also supply any variety of fruit trees, shade trees, small fruits and strawberry plants at equally low prices. Write for special quotations.

\section{LILIES}

Hardy lilies have attained a prominent place in recent years. Here are a few of the very best.

PRICES-Each 35c, 3 for 90c, 10 for $\$ 2.75$ (large bulb) Each 50c, 3 for $\$ 1.35,10$ for $\$ 4.00$ (extra large buib)

Auratum-Large flower heads. White, studded with crimson maroon.

Candium (Madonna Lily)—White and very fragrant.

Elegans (Red Russian Lily)_Dwarf, gold with velvety red inside. Hardy, and blooms freely.

Giganteum-Most majestic of lilies. July to August bearing immense, long, white, trumpet shaped fragrant flowers.

\section{CANNAS}

PRICES-15c each, 5 for 55c, 10 for $\$ 1.00$

The President-Immense flaming scarlet. 4 feet. King Humbert--Scarlet flowers, bronze leaves. Apricot-Buff yellow base overspread with salmon pink.

\section{LANDSCAPE SERVICE}

Our landscape department is in charge of a graduate landscape architect. If you have a new home, or are interested in some public planting project, or want your old home grounds redesigned, we are in a position to be of real service to you. We will be glad to submit to you suggestive pencil sketches of your grounds or project without charge, or if you desire, up to the minute, elaborate design and planting plans we can produce them for you at a very nominal fee. Write us for further information. 


\section{TERMS AND CONDITIONS}

TERMS-Cash before shipment, unless special agreement has been made for other terms of payment or previous credit has been established with us.

SHIPPING SEASON-Generally begins April 1st and continues to June 15. Fall season from August 15 th to Nov. 1st. All stock is dug fresh and packed in best quality live Sphagnum moss. Some seasons we can begin digging as early as April 1st.

OUR RESPONSIBILITY for delivery ceases when delivery is made by us to transportation company. Under no circumstances will goods be shipped subject to approval or rejection on arrival.

SHIPPING DIRECTIONS-Please state distinctly whether you want the goods sent by freight or express and tell us what railroad to ship by if you have a preference.

SPECIAL PRICES given on very large orders. 50 of any one variety and sizes sold at 100 rates, and 500 of any one variety and size, at 1000 rates.

ALL goods travel at purchaser's risk and expense.

PRICES in this catalog supersede all previous quotations.

CLAIMS for deduction will receive consideration only when made within six days after receipt of goods.

CAUTION-All quotations are made subject to stock being unsold when order is received and to injury to stock from causes over which we have no control.

INSPECTION-Our nurseries are inspected annually by the State Entomologist, and we hold his certificate that our stock is free from injurious insects and contagious diseases.

PERSONAL SELECTION-Stock specially selected by customers at the nursery, will be charged for according to value of trees chosen, irrespective of catalog list price.

Clean Certificate of Inspection accompanies every shipment 


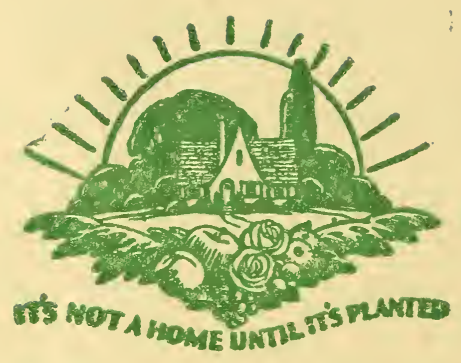

